\title{
Sleep Pharmacotherapy for Common Sleep @ checkererudatas Disorders in Pregnancy and Lactation
}

\author{
Margaret A. Miller, MD; Niharika Mehta, MD; Courtney Clark-Bilodeau, MD; and Ghada Bourjeily, MD
}

\begin{abstract}
Sleep disturbances are common in pregnancy, and sleep disorders may worsen or present de novo in the course of gestation. Managing a pregnant patient is complicated by the risk of teratogenicity, pharmacokinetic changes, and the dynamic nature of pregnancy. Although nonpharmacologic interventions are likely safest, they are often ineffective, and a patient is left dealing with frustrations of the sleep disturbance, as well as the negative outcomes of poor sleep in pregnancy. As with any other condition in pregnancy, management requires an understanding of pregnancy physiology, knowledge of the impact of a given condition on pregnancy or fetal and neonatal outcomes, and an ability to weigh the risk of the exposure to an untreated, or poorly treated condition, against the risk of a given drug. In partnership with the pregnant patient or couple, options for therapy should be reviewed in the context of the impact of the condition on pregnancy and offspring outcomes, while understanding that data (positive or negative) on the impact of therapy on perinatal outcomes are lacking. This article reviews the epidemiology of sleep disorders in pregnancy, general principles of prescribing in pregnancy and lactation, and safety surrounding therapeutic options in pregnancy.
\end{abstract}

CHEST 2020; 157(1):184-197

KEY WORDS: insomnia; lactation; pregnancy; restless legs syndrome; sleep-disordered breathing

Sleep disturbances are a common occurrence in peripartum women. According to the National Sleep Foundation poll performed two decades ago, nearly $80 \%$ of women experience disturbed sleep at some point during pregnancy. ${ }^{1}$ Many pregnancy-specific changes may affect sleep continuity and sleep architecture, worsen preexisting sleep conditions, or lead to de novo development of sleep disorders. Hormonal shifts in pregnancy and lactation modify sleep architecture, ${ }^{2,3}$ increase neuronal activity, affect respiratory drive, and control fluid distribution. ${ }^{4}$ Anatomical and physiological factors such as ligament stretching, uterine contractions, or fetal movement result in sleep disruption and sleep fragmentation. ${ }^{5}$ The respiratory system undergoes significant physiological changes that may influence breathing during sleep; namely, functional residual capacity is reduced in late pregnancy, with more pronounced reductions in the supine position. The rise in reproductive hormone levels and the increase in plasma volume and interstitial volume may lead to upper airway edema and nasal congestion. ${ }^{6}$ Together with these changes, physiological weight gain and its central distribution in pregnancy may have an effect on breathing during sleep.
ABBREVIATIONS: CBT-I = cognitive behavioral therapy for insomnia; $\mathrm{FDA}=$ US Food and Drug Administration; PLLR = Pregnancy and Lactation Labeling Rule; RLS = restless legs syndrome

AfFiliations: From the Warren Alpert Medical School of Brown University, Providence, RI.
CORRESPONDENCE TO: Ghada Bourjeily, MD, The Miriam Hospital, Warren Alpert Medical School of Brown University, 146 W River St, Providence, RI 02904; e-mail: ghada_bourjeily@brown.edu

Copyright $@ 2019$ American College of Chest Physicians. Published by Elsevier Inc. All rights reserved.

DOI: https://doi.org/10.1016/j.chest.2019.09.026 
Metabolic physiological changes of pregnancy may also affect sleep disorders, such as restless legs syndrome (RLS)/Willis-Ekbom disease, during pregnancy. For instance, folate and iron demands are higher in pregnancy due to the growing demands of the conception products. ${ }^{7}$ Hence, all these physiological changes are accompanied by a high prevalence of sleep disorders and disturbances in pregnancy, and clinicians are challenged with the management of these disorders in this complex population.

Because treatment of many of these conditions may involve pharmacotherapy, decisions regarding when and who to treat, as well as the best approach for the mother and her unborn child, can be complicated by drug safety and pharmacodynamic parameters. The current article reviews the decision-making process of prescribing in the peripartum period in general, for sleep disorders in particular, and provides an overview of medications used in some of the more common conditions encountered by pregnant and lactating women.

\section{Epidemiology of Sleep Disorders in Pregnancy}

The literature suggests a higher incidence of sleep disorders in pregnancy, including insomnia, RLS, and sleep-disordered breathing. In the general population, insomnia is twice as prevalent in women as in men. Chronic sleep loss and insomnia, often accepted as a natural consequence of pregnancy, are common and become notably worse with pregnancy progression. Insomnia in pregnancy has been reported by $5 \%$ to $38 \%$ of women ${ }^{8,9}$ in early pregnancy, with a prevalence in late pregnancy reported as high as $60 \% .{ }^{10}$ RLS is common during pregnancy, affecting approximately one in five pregnant women in Western countries. ${ }^{11}$ Prevalence of this disorder increases with pregnancy progression.

Narcolepsy, which affects one in 2,000 people, ${ }^{12}$ shows no female predominance nor predilection for worsening in pregnancy. However, narcolepsy is an important consideration in perinatal patients due to concern for medication safety in pregnancy and breastfeeding, the prevalence of poor sleep (including added factors leading to sleep restriction postpartum), and the potential influence of the disorder on pregnancy outcomes and mode of delivery. In a retrospective cohort study of 249 women with narcolepsy, a higher incidence of impaired glucose tolerance, anemia, and delivery by cesarean section was noted. Neonatal care was adversely affected by symptoms of narcolepsy in $60.1 \%$ of neonates born to mothers with narcolepsy. ${ }^{13}$ Albeit rare, labor-induced cataplexy has been reported ${ }^{14}$ and may contribute to an increased incidence of delivery by cesarean section.

Snoring occurs at an increased frequency in pregnancy and can affect up to one-third of pregnant women by the third trimester, ${ }^{15}$ with longitudinal studies showing that the incidence of habitual snoring increases from the first trimester to the third trimester. ${ }^{16}$ The prevalence of objectively measured sleep-disordered breathing also increases with pregnancy progression and has varied from $4 \%$ to $70 \% .{ }^{17-21}$ This wide range of prevalence can be explained by variations in methods and technology used to define sleep-disordered breathing, as well as differences in populations studied (low-risk vs complicated pregnancies).

With this high prevalence of sleep disturbances and disorders affecting the pregnant population, decisions regarding pharmacotherapy in the peripartum period can be complicated and need to be considered in a systematic fashion.

\section{Prescribing in Pregnancy}

Prescribing medications in pregnant and lactating women poses a unique challenge for clinicians. Concerns include the potential toxicity of drugs to the fetus and breastfeeding infant, and alterations in pharmacokinetic parameters that may require changes in dosing. Despite studies showing a rise in medication use in pregnancy in the United States, ${ }^{22}$ there is a significant lack of clinical trials, and a limited understanding of the effects of medications on the longterm health of infants and mothers. As a result, discontinuing a medication in pregnancy may seem like the safest course. However, untreated or poorly controlled conditions most often pose a greater risk to the pregnant woman and her infant than the risk of the medication use.

Faced with this dilemma, many clinicians have relied heavily on the US Food and Drug Administration (FDA) drug categories for pregnancy (ABCDX). However, in 2015, the FDA retired this system. After a lengthy process of review, the FDA concluded that the letter categories were flawed for several reasons: (1) the letter categories system was almost exclusively derived from animal data; (2) it was perceived as a simple gradient of risk that failed to differentiate severity and range of adverse outcomes; (3) the system failed to address the 
Figure 1 - Approach to pharmacotherapy in pregnant women with a sleep condition.

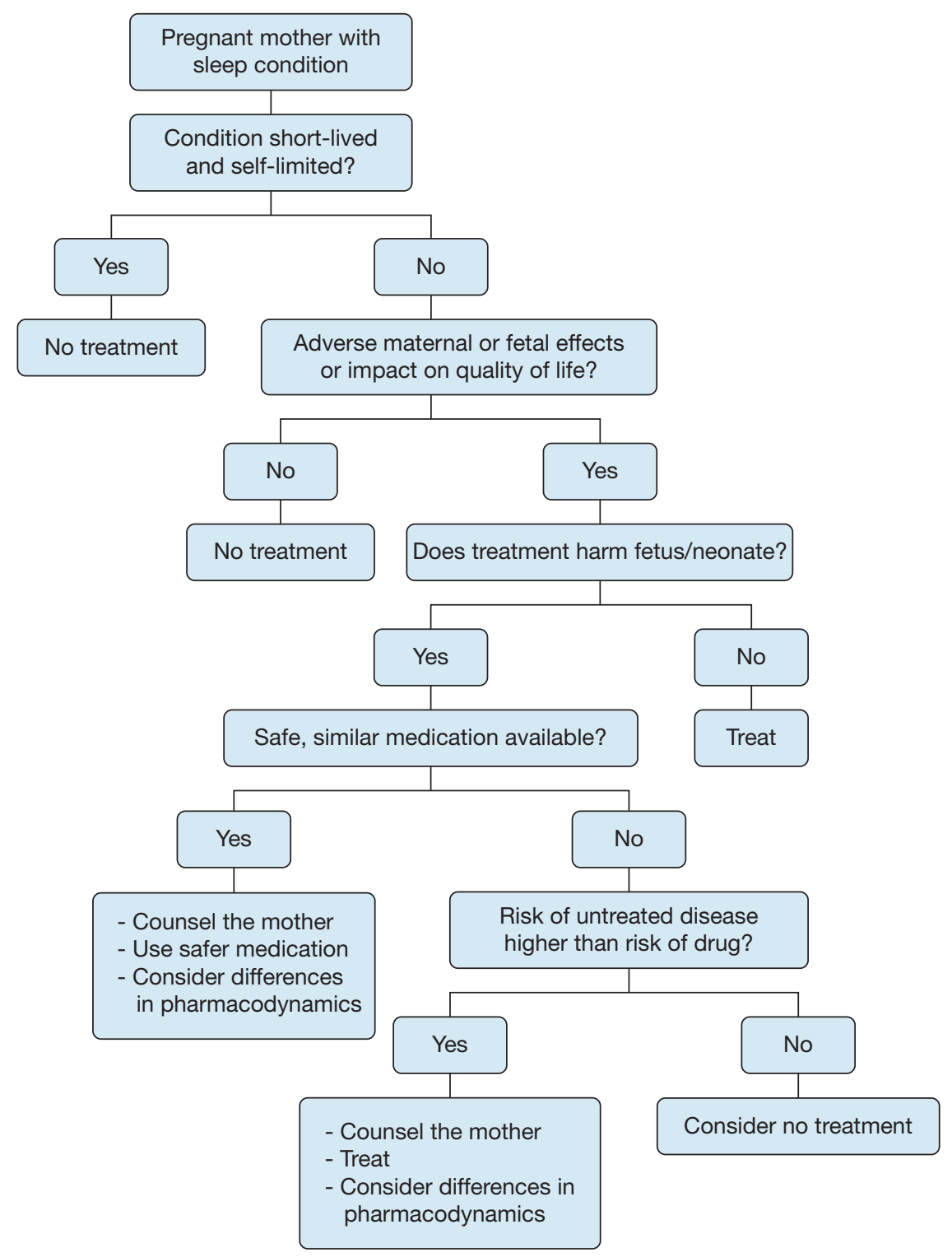

importance of dose, route, and gestational timing; and (4) it did not consider indication for the drug or have a mechanism that weighs the risk of the drug against the risk of the untreated condition. In addition, there was no requirement for updating the categories. The conclusion of the FDA was that the pregnancy categories were often misinterpreted and misused.

In 2015, the ABCDX categories were replaced by the FDA Pregnancy and Lactation Labeling Rule (PLLR). This new ruling requires narrative text that will provide prescribers with relevant information for critical decision-making when treating pregnant or lactating women. The PLLR includes a more complete statement of the known risks based on the best available data. The new format will encourage the consideration of the untreated disease, will present animal data in the context of human exposure, and explicitly state when human data are available and when no data are available. The new rule includes three categories: (1) pregnancy, including labor and birth; (2) lactation; and (3) female and male subjects of reproductive potential. ${ }^{23}$ The goal of the PLLR is to provide prescribers with relevant information for decision-making when treating pregnant or lactating women. In all cases of prescribing in pregnancy, the clinician must weigh the potential risk of medication vs the risk of untreated disease (Fig 1). A shared decision-making approach is important. Clinicians must provide women with accurate safety information regarding medication use in pregnancy but also be sensitive to the patient and families' concerns about risk of medication use in pregnancy. 
Useful online resources for information on drugs in pregnancy include Reprotox and MotherToBaby. ${ }^{24,25}$

\section{Prescribing in Breastfeeding Women}

The preferred method of infant feeding is exclusive breastfeeding for at least 6 months, with continuation for $\geq 1$ year due to the numerous short- and long-term benefits provided to the mother and her infant. Suboptimal breastfeeding also negatively affects public health and contributes to the high societal costs of maternal and infant death and disease. ${ }^{26}$ Accepting breastfeeding as the normative standard for infant feeding, clinicians must face the challenge of determining a medication's safety in breastfeeding. First, consideration should be made for how the medication can affect maternal milk supply and for the mother's ability to perform infant care, such as not causing excessive sedation. Next, it should be determined if the medication is orally bioavailable (ie, if a medication can be absorbed via the infant's GI tract), although the majority of medications used for sleep disorders are formulated for the oral route and are, generally, orally bioavailable. A final task is determining the safety of drug exposure in breast milk. During the earliest postpartum days, more medication penetrates into the breast milk compared with later periods due to wide paracellular pathways between mammary epithelial cells. However, the newborn's low volume of milk intake typically translates into a small medication dose exposure. In general, medications are more likely to be transferred into breast milk if they have high concentrations in the maternal plasma, are lipophilic, have a smaller molecular weight, and are less protein bound. ${ }^{27}$ Further concerns for potential infant toxicity include specific infant characteristics, including age, size, and health. A database source such as LactMed ${ }^{28}$ is a helpful decision-making tool outlining these drug specifications.

\section{Pharmacotherapy for Common Sleep Conditions}

The current review discusses therapy of common sleep conditions that are either exacerbated by pregnancy, or those known to affect or be affected by pregnancy. In general, the decision to use pharmacotherapy should consider the disease and its impact on the mother and fetus, the drug's efficacy and safety profile, and potential cultural considerations and preferences of the mother and/or couple (Fig 1).
Treatment Considerations for Insomnia in Pregnancy

There is mounting evidence suggesting that chronic sleep loss may be associated with an increased risk of mortality, cardiovascular disease, diabetes, and obesity ${ }^{29}$ mediated by hormonal, metabolic, and inflammatory mechanisms. Studies have also indicated that adverse pregnancy outcomes such as perinatal depression, gestational diabetes, preeclampsia, ${ }^{30}$ preterm birth ${ }^{31}$ and adverse fetal outcomes, ${ }^{32}$ postpartum anxiety, ${ }^{33}$ and depression ${ }^{10,34}$ occur in women with chronic sleep loss. Palagini et $\mathrm{al}^{32}$ suggest a pathophysiological mechanism for adverse pregnancy outcomes in which conditions of stress, such as insomnia, result in an allostatic load that in turn results in neuroendocrine alterations that cause chronic sleep loss in a vicious cycle. The authors propose that, similar to other relevant biopsychosocial risk factors, screening and treatment of insomnia may prevent stress-related perinatal complications.

Nonpharmacologic management of insomnia in pregnancy includes good sleep hygiene such as establishing regular sleep-wake cycles, stimulus control, minimizing fluid intake prior to bed to decrease nocturia, avoiding caffeine intake close to bedtime, minimizing restrictions on sleep, addressing physical discomfort, cognitive behavioral therapy for insomnia (CBT-I), exercise, meditation, ${ }^{35}$ and acupuncture. Alcohol and cannabinoids are substances that are resorted to in some patients experiencing insomnia. The fetal effects of alcohol use in pregnancy are discussed by obstetric providers, although the safe dose of alcohol consumption is debated. Clear guidance on the use of cannabis in pregnancy is lacking. Cannabis use in pregnancy is increasing, and the substance is mostly used for nonmedicinal reasons. ${ }^{36}$ However, it has been directly marketed for the treatment of nausea of pregnancy despite evidence of harm. ${ }^{37}$ In a recent registry-based study, cannabis use was associated with preterm birth and small-for-gestational-age birth. ${ }^{38}$

Pregnant women ${ }^{39}$ and couples ${ }^{40}$ often prefer nonpharmacologic measures, such as CBT-I, over medications or even acupuncture. A recently published randomized controlled trial showed that pregnant women randomized to undergo CBT-I experienced a significantly greater reduction in insomnia severity and faster remission of insomnia compared with women assigned to a control intervention. ${ }^{41}$ Preliminary evidence from a small trial showed improvement in symptoms of depression, pregnancy-specific anxiety, 
and fatigue, following treatment with CBT-I. ${ }^{42}$ The impact of interventions to treat insomnia on maternal or fetal outcomes remains to be examined, however.

Table 1 presents pharmacotherapy options for insomnia in pregnancy and lactation. ${ }^{24,43-69}$ Women who do not respond to nonpharmacologic therapy and need medication prescription can be counseled accordingly. The effect of exogenous melatonin in pregnancy is not well studied, with conflicting results in mouse models. ${ }^{70,71}$ Although there are concerns regarding exogenous melatonin administration in pregnancy and its impact on the development of circadian rhythms and reproductive function in the offspring, exogenous melatonin may also have some potential fetal protective effects. For instance, an ongoing trial is testing the neuroprotective effect of exogenous melatonin administration in fetuses diagnosed with growth restriction. $^{72}$ The efficacy of melatonin in the treatment of insomnia in pregnancy remains to be determined. Antihistamines are widely used in pregnancy, although few studies confirm their safety profiles in humans. Pregnant women randomly assigned to receive trazodone or diphenhydramine in one trial had significant improvement in sleep duration and sleep efficiency compared with placebo at 2 and 6 weeks. ${ }^{73}$

\section{Key Points:}

- Nonpharmacologic interventions preferred.

- Use of some drugs such as zopiclone and trazodone may be justified (Table 1).

- Neonatal withdrawal is possible with many drugs used in late pregnancy.

- Most drugs are excreted in breast milk, and their use in lactating women is not advisable.

\section{RLS/Willis-Ekbom Disease}

RLS has been associated with increased odds of sleepwake disturbances such as poor sleep, poor daytime function, and excessive daytime sleepiness in pregnancy. ${ }^{74}$ There also seems to be an association between hypertensive disorders of pregnancy and RLS diagnosed by using international RLS criteria in some studies, ${ }^{75,76}$ in which women with RLS are more likely to have a hypertensive disorder of pregnancy. Conversely, pregnant women with hypertensive disorders also seem to have a higher risk of meeting RLS criteria, ${ }^{77}$ suggesting a potential metabolic process underlying the pathogenesis of RLS in pregnancy and a possible bidirectional relation. This potential association with an adverse cardiovascular condition emphasizes the need to better understand the impact and safety of pharmacotherapy for RLS in pregnancy. ${ }^{78}$

There are currently limited safety data on the use of first-line drugs in pregnancy, which complicates treatment of this condition and restricts the therapeutic options. Iron supplementation is indicated when serum ferritin levels are $<30 \mathrm{ng} / \mathrm{mL}$ in general; however, in RLS, supplementation was suggested by consensus practice guidelines if levels drop to $<75 \mathrm{ng} / \mathrm{mL}$. ${ }^{11}$ Both oral and IV preparations seem to be safe in pregnancy. Oral iron administration is initiated first, with IV administration reserved for women who do not respond to oral supplementation and those with suspected malabsorption or inability to tolerate oral preparations. Use of IV iron before 13 weeks of gestation is not recommended by the European Medicine Agency's Committee of Medicinal Products for Human Use. The FDA, however, does not currently restrict IV iron administration to the second and third trimester. ${ }^{79}$ Iron sucrose is the preparation used in the majority of studies on IV iron use in pregnancy; however, all currently available IV iron preparations are considered safe and effective. ${ }^{80}$ Follow-up testing of hemoglobin and ferritin levels and monitoring of symptoms are recommended to determine treatment response.

Use of other pharmacologic options such as second- or third-line drugs may also be justified (Table 2), and women should be counseled accordingly. In the case of use of drugs known to lead to neonatal withdrawal or respiratory drive depression, consultation with neonatology prior to delivery is advised.

Key Points:

- Treat with iron supplementation is suggested if iron stores are low.

- Some non-first-line drugs such as clonazepam, clonidine, and opioids may be justified depending on severity. Neonatal withdrawal is a concern with these drugs, especially because RLS/WillisEkbom disease is more prevalent in late pregnancy.

- Some drugs that may be teratogenic and not used in pregnancy may be safe with breastfeeding.

\section{Treatment Considerations for Narcolepsy in Pregnancy}

Treatment options for narcolepsy in pregnancy may be severely limited due to lack of data evaluating medication safety of stimulants and rapid eye movement suppressants. Nonpharmacologic 
TABLE 1 ] Pharmacotherapy for Insomnia in Pregnancy and Lactation

\begin{tabular}{|c|c|c|}
\hline Agent & Pregnancy Safety & Lactation \\
\hline Amitriptyline & $\begin{array}{l}\text { Possible effect on embryo development in } \\
\text { experimental animals. Large-scale human } \\
\text { studies and case-control data: no association } \\
\text { with congenital malformations }{ }^{43,44} \text { but possible } \\
\text { newborn withdrawal symptoms. Notify } \\
\text { pediatrician }\end{array}$ & $\begin{array}{l}\text { Distributed in milk at concentrations of } 1.9 \% \text { the } \\
\text { weight adjusted maternal daily dose. } \\
\text { AAP: effect unknown }{ }^{45} \text {; WHO: Compatible with } \\
\text { breastfeeding in doses up to } 150 \mathrm{mg} / \mathrm{d}^{46}\end{array}$ \\
\hline Diphenhydramine & $\begin{array}{l}\text { Animal studies: drug not expected to increase the } \\
\text { risk of congenital malformations. }{ }^{47} \text { Some } \\
\text { reports suggest that first-trimester use may be } \\
\text { associated with various (rather than a single) } \\
\text { anomalies }^{48,49}\end{array}$ & $\begin{array}{l}\text { Manufacturer advises against the use in lactating } \\
\text { mothers, especially in premature newborns. } \\
\text { However, no major adverse effects have been } \\
\text { reported }\end{array}$ \\
\hline Doxepin & $\begin{array}{l}\text { Animal studies and scarce human reports: Not } \\
\text { expected to increase the risk of congenital } \\
\text { malformations. Pregnancy registry exists }\end{array}$ & $\begin{array}{l}\text { A small amount is detected in breast milk. } \\
\text { However, reports of muscle hypotonia and } \\
\text { respiratory depression exist. WHO: drug } \\
\text { incompatible with breastfeeding }\end{array}$ \\
\hline Estazolam & $\begin{array}{l}\text { Effect of the drug on pregnancy in animals or } \\
\text { humans has not been studied. Pregnancy } \\
\text { registry exists }\end{array}$ & Excreted in rat breast milk but no human studies \\
\hline Ramelteon & $\begin{array}{l}\text { Fertility: No changes in ovulation or menses were } \\
\text { observed in a double-blind placebo trial. }{ }^{51} \\
\text { Animal studies: dose-dependent incidence of } \\
\text { diaphragmatic hernia and scapular shape } \\
\text { abnormalities in rats }{ }^{52} \text { but not at high doses in } \\
\text { rabbits. } \\
\text { Human data are lacking }\end{array}$ & $\begin{array}{l}\text { Ramelteon in rat breast milk. } \\
\text { No human data on lactation are available }\end{array}$ \\
\hline Suvorexant & $\begin{array}{l}\text { Animal: Reduction in fetal rat body weight } \\
\text { following exposure to high doses but no effect } \\
\text { on fertility, embryo survival, or adverse fetal } \\
\text { effects in rabbits at high doses. No human } \\
\text { studies }\end{array}$ & High concentration in breast milk in rats \\
\hline Temazepam & $\begin{array}{l}\text { Contraindication in product labeling is based on } \\
\text { findings with other benzodiazepines. Early data } \\
\text { on diazepam and chlordiazepoxide use in first } \\
\text { trimester suggesting increased risk of cleft } \\
\text { palate were not supported by later studies. } \\
\text { Concern about neonatal withdrawal with late } \\
\text { third-trimester use. Concomitant use with } \\
\text { diphenhydramine has been associated with } \\
\text { fetal death. }{ }^{53} \text { First-trimester exposure was not } \\
\text { associated with anomalies in } 379 \\
\text { pregnancies }\end{array}$ & $\begin{array}{l}\text { WHO: Occasional use of benzodiazepines in } \\
\text { breastfeeding mothers is acceptable }\end{array}$ \\
\hline Trazodone & $\begin{array}{l}\text { Animal: At highest dose levels, trazodone was } \\
\text { associated with decrease in fetal viability in } \\
\text { rats. Human: Not likely to result in major } \\
\text { congenital malformations based on small } \\
\text { human studies }{ }^{55-57}\end{array}$ & $\begin{array}{l}\text { Distributed in milk but in small amounts. }{ }^{58} \\
\text { Milk-to-plasma ratio is } 0.14 \text {. Active metabolites } \\
\text { of trazodone are excreted in milk }\end{array}$ \\
\hline Zaleplon & $\begin{array}{l}\text { Animal: High doses associated with adverse } \\
\text { effects on female (but not male) fertility, } \\
\text { stillbirth, decreased pup growth, and delayed } \\
\text { development in rats, but associations not seen } \\
\text { at lower doses. } \\
\text { Study of } 32 \text { pregnant women suggests no } \\
\text { increased risk of teratogenicity. However, } \\
\text { numbers were too small to be conclusive }{ }^{59}\end{array}$ & $\begin{array}{l}\text { Estimated infant dose }<0.02 \% \text { the maternal } \\
\text { dose. }{ }^{60} \text { Unlikely to adversely affect the } \\
\text { neonate, but there are no available studies that } \\
\text { evaluated consequences of such exposure }\end{array}$ \\
\hline $\begin{array}{l}\text { Zopiclone or } \\
\text { eszopiclone }\end{array}$ & $\begin{array}{l}\text { Animal: Arrested spermatogenesis in rats, } \\
\text { partially reversible, } \\
\text { surviving pups. Human: Study of } 1,143 \\
\text { exposures in first trimester and } 897 \text { in second }\end{array}$ & $\begin{array}{l}\text { Estimated infant dose about } 3.2 \% \text { of maternal } \\
\text { dose. }{ }^{65} \text { Unlikely toxicity but effects of chronic } \\
\text { exposure unknown }\end{array}$ \\
\hline
\end{tabular}

(Continued) 


\begin{tabular}{|c|c|c|}
\hline Agent & Pregnancy Safety & Lactation \\
\hline & $\begin{array}{l}\text { and third trimesters showed no increased risk } \\
\text { of malformations. }{ }^{62} \text { Other smaller studies } \\
\text { showed similar results. }{ }^{63,64} \text { Crosses placental } \\
\text { barrier and withdrawal reported at birth }{ }^{65}\end{array}$ & \\
\hline Zolpidem & $\begin{array}{l}\text { Animal: High doses are associated with irregular } \\
\text { estrous cycles and delayed ossification of fetal } \\
\text { bones. Human: Transplacental transfer of } \\
\text { zolpidem is documented. Study of } 603 \\
\text { pregnancies with zolpidem exposure showed } \\
\text { possible increased risk of GI malformations. } \\
\text { However, findings not confirmed in other } \\
\text { studies. Population- based study in Taiwan } \\
\text { ( } 2,497 \text { exposed women and } 12,485 \\
\text { unexposed) showed an increased risk of low } \\
\text { birth weight and preterm deliveries in women } \\
\text { but no increased risk of congenital anomalies. } \\
\text { Flaccidity and withdrawal symptoms might } \\
\text { occur }\end{array}$ & $\begin{array}{l}\text { Estimated infant dose }<0.02 \% \text { the maternal } \\
\text { dose. }^{67} \text { AAP: safe for lactation }{ }^{45}\end{array}$ \\
\hline $\begin{array}{l}\text { Exogenous } \\
\text { melatonin }^{a}\end{array}$ & $\begin{array}{l}\text { Crosses the placenta and reaches the fetus in late } \\
\text { pregnancy in many species, which raises } \\
\text { concerns for potential interference with the } \\
\text { development and entrainment of the } \\
\text { offspring's circadian rhythm }^{68} \text { and possibly } \\
\text { reproductive alterations }\end{array}$ & $\begin{array}{l}\text { Transferred into breast milk and may play a role } \\
\text { in postnatal development of sleep pattern. No } \\
\text { data on exogenous melatonin administration; } \\
\text { however, it is possible that it may theoretically } \\
\text { interfere with that process }{ }^{24}\end{array}$ \\
\hline
\end{tabular}

$\mathrm{AAP}=$ American Academy of Pediatrics; $\mathrm{WHO}=$ World Health Organization .

a Melatonin is not considered a drug per se.

interventions such as avoidance of medications that can exacerbate daytime sleepiness, intermittent napping, and practicing good sleep hygiene can be of immense value. A survey of sleep specialists worldwide suggested that risks of narcolepsy medications in pregnancy are often overestimated and treatment stopped or reduced during pregnancy. ${ }^{81}$ The decision to withdraw or continue stimulant or anticataplectic medications should essentially be individualized, and the risk of untreated disease weighed against that of exposure of the fetus to these medications.

Pharmacologic treatment would be appropriate in those with severe symptoms that may jeopardize maternal, and therefore fetal, safety due to risk of falls and motor vehicle accidents.

Table 3 summarizes the data available on stimulants and rapid eye movement suppressants. ${ }^{24,82-97}$ Mothers should be counseled about the potential teratogenic risk of some drugs and the association of drug use with other adverse outcomes such as behavioral changes or longterm neurodevelopment impairment. ${ }^{24}$ Based on recent registry data, modafinil is associated with major congenital anomalies. Hence, women of reproductive age should be advised of the potential risk, should have a negative pregnancy test result prior to drug initiation, and need to be using effective contraception. ${ }^{83}$ The postpartum period is more complicated by sleep restriction related to the newborn's needs and the fact that many of the stimulants have small molecular weight, leading to transfer into breast milk and medication staying in breast milk for a few hours. However, it may be possible for women to breastfeed intermittently and to time feeding away from medication doses. ${ }^{95}$

Key Points:

- Many drugs used to treat narcolepsy may be teratogenic.

- Treatment should be individualized, and the clinician needs to assess risk of untreated disease against risk of potential teratogenicity. Mothers should be counseled accordingly.

- The postpartum period is complicated by sleep restriction due to nocturnal newborn needs.

- Most drugs have small molecular weight and are believed to transfer into breast milk.

\section{Treatment Considerations for Sleep-Disordered Breathing in Pregnancy}

Although the mainstay of therapy for sleep-disordered breathing is nonpharmacologic, treatment of associated comorbidities such as rhinitis or asthma is often needed. 
TABLE 2 ] Prescribing for Willis-Ekbom Disease in Perinatal Women

\begin{tabular}{|c|c|c|}
\hline Agent & Pregnancy & Lactation \\
\hline Bromocriptine & $\begin{array}{l}\text { Not believed to increase risk of anomalies. Used in } \\
\text { prolactinomas. Weigh risk vs benefit }\end{array}$ & $\begin{array}{l}\text { No reports of toxicity. May reduce } \\
\text { lactation }\end{array}$ \\
\hline Cabergoline & $\begin{array}{l}\text { Not believed to increase risk of anomalies. Use in fertility } \\
\text { treatment }\end{array}$ & Reduces prolactin levels \\
\hline $\begin{array}{l}\text { Carbamazepine } \\
\text { (approved for } \\
\text { indication) }\end{array}$ & $\begin{array}{l}\text { Teratogenic; neural tube defects and possibly craniofacial } \\
\text { anomalies. Benefit for persistent seizures may outweigh } \\
\text { risk but not in RLS. Vitamin K supplement in late } \\
\text { pregnancy, evidence limited }\end{array}$ & Compatible as levels too low \\
\hline Clonazepam & $\begin{array}{l}\text { Neonatal withdrawal; effect further potentiated by } \\
\text { concomitant SSRI }\end{array}$ & $\begin{array}{l}\text { Possible sedating effects if drug } \\
\text { accumulation }\end{array}$ \\
\hline $\begin{array}{l}\text { Clonidine } \\
\text { (approved but } \\
\text { off-label) }\end{array}$ & $\begin{array}{l}\text { No structural anomalies expected (animals). Possible } \\
\text { behavioral changes in neonates (animals and humans) }\end{array}$ & $\begin{array}{l}\text { Minimally excreted in breast milk. } \\
\text { Observe for hypotension; may reduce } \\
\text { milk production }\end{array}$ \\
\hline $\begin{array}{l}\text { Gabapentin } \\
\text { (approved for } \\
\text { indication) }\end{array}$ & $\begin{array}{l}\text { Fetal growth impairment and developmental delays in } \\
\text { animal studies. Human data conflicting and true risk } \\
\text { unknown }\end{array}$ & $\begin{array}{l}\text { Levels in breast milk } 1 \%-4 \% \text { of weight- } \\
\text { adjusted maternal dose. No known } \\
\text { adverse effects in exposed neonates }\end{array}$ \\
\hline $\begin{array}{l}\text { Levodopa } \\
\text { (approved but } \\
\text { off-label) }\end{array}$ & $\begin{array}{l}\text { Adverse pregnancy and fetal outcomes in animals at high } \\
\text { doses. Limited human data suggest no adverse effects }\end{array}$ & $\begin{array}{l}\text { May affect lactation by reducing } \\
\text { prolactin. No other pediatric concerns }\end{array}$ \\
\hline $\begin{array}{l}\text { Opioids (approved } \\
\text { but off-label) }\end{array}$ & Neonatal withdrawal & May be sedating to newborn \\
\hline $\begin{array}{l}\text { Pramipexole } \\
\text { (approved for } \\
\text { indication) }\end{array}$ & $\begin{array}{l}\text { Human safety data very limited to case reports and case } \\
\text { series }\end{array}$ & $\begin{array}{l}\text { Secretion in breast milk not known. May } \\
\text { affect lactation by reducing prolactin }\end{array}$ \\
\hline $\begin{array}{l}\text { Pregabalin } \\
\text { (approved but } \\
\text { off-label use) }\end{array}$ & $\begin{array}{l}\text { Adverse effects on animal development. Limited human } \\
\text { data }\end{array}$ & $\begin{array}{l}\text { No data on transfer in breast milk but } \\
\text { passage is probable }\end{array}$ \\
\hline $\begin{array}{l}\text { Ropinirole } \\
\text { (approved for } \\
\text { indication) }\end{array}$ & No human data. Animal data do not show malformations & $\begin{array}{l}\text { Secretion in breast milk not known. May } \\
\text { affect lactation by reducing prolactin }\end{array}$ \\
\hline Tramadol & $\begin{array}{l}\text { First-trimester exposure in Swedish registry showed a } \\
\text { small increase in risk for cardiovascular anomalies and } \\
\text { clubfoot; not confirmed by other studies }\end{array}$ & $\begin{array}{l}\text { Potential respiratory depression as } \\
\text { roughly } 3 \% \text { equivalent of typical } \\
\text { newborn IV dose transferred via } \\
\text { breast milk }\end{array}$ \\
\hline Valproic acid & Teratogenic; use not justified & Justified use: AAP and WHO \\
\hline
\end{tabular}

SSRI = selective serotonin reuptake inhibitors. See Table 1 legend for expansion of other abbreviations.

Rhinitis: Pregnancy is associated with hyperemia and edema of the nasal mucosa. As a result, $20 \%$ to $30 \%$ of pregnant women develop a form of nasal congestion, often referred to as "pregnancy rhinitis." Preexisting nasal congestion may also worsen in pregnancy. Multiple studies have established that nasal congestion leads to sleep disturbance with potential consequences of sleep-disordered breathing, insomnia, or daytime somnolence. Treatment of nasal congestion has been associated with improved symptoms and improved sleep in the general population ${ }^{98}$; however, there are no data showing improved outcomes in pregnancy.

Nonpharmacologic approaches to persistent rhinitis such as saline nasal sprays, nasal irrigation, ${ }^{83}$ or even adhesive nasal strips can be helpful and may be used prior to pharmacologic intervention.

Preferred topical steroids include fluticasone furoate, mometasone, or budesonide. ${ }^{99}$ Triamcinolone has been associated with a risk of congenital defects of the respiratory track ${ }^{100}$ and is best avoided in pregnancy. Although there are no studies on intranasal cromolyn sodium in pregnancy, inhaled cromolyn sodium has been found to be safe in several trials. ${ }^{101}$ Given its minimal systemic absorption, nasal cromolyn sodium is likely a safe choice. Of the first-generation oral antihistamines, chlorpheniramine has been found to be safe in animal and human studies, but its use may be limited by side effects. Second-generation antihistamines 
TABLE 3 ] Pharmacotherapy for Narcolepsy in Pregnancy and Lactation

\begin{tabular}{|c|c|c|}
\hline Agent & Pregnancy Safety & Lactation \\
\hline Amphetamines & $\begin{array}{l}\text { Likely no significant teratogenic risk, however, } \\
\text { limited data suggest an effect on growth, } \\
\text { neonatal behavior, and long-term } \\
\text { neurodevelopment }{ }^{24}\end{array}$ & $\begin{array}{l}\text { Animal studies: Long-term behavioral effects, } \\
\text { including learning and memory deficits and } \\
\text { altered locomotor activity, were observed. } \\
\text { Human studies are scarce. Breastfeeding is } \\
\text { generally discouraged with maternal } \\
\text { amphetamine use }\end{array}$ \\
\hline Armodafinil & $\begin{array}{l}\text { Armodafinil is the } R \text {-enantiomer of modafinil. } \\
\text { Similar to modafinil, the drug has recently } \\
\text { been associated with an increase in the risk of } \\
\text { major congenital malformations, including } \\
\text { cardiac anomalies }^{83}\end{array}$ & $\begin{array}{l}\text { Very limited human data. One case report } \\
\text { suggesting very little passage into milk }\end{array}$ \\
\hline Clomipramine & $\begin{array}{l}\text { Possible increase in the risk of cardiac } \\
\text { malformations. }{ }^{85} \text { Increased risk of transient } \\
\text { neonatal complications as seen with SSRIs }\end{array}$ & $\begin{array}{l}\text { Small amount found in breast milk, not enough } \\
\text { to prevent withdrawal symptoms in infants } \\
\text { with prenatal exposure to clomipramine }\end{array}$ \\
\hline Fluoxetine & $\begin{array}{l}\text { No significant association with birth defects. } \\
\text { Transient neonatal complications with third- } \\
\text { trimester use. Risk of social-behavioral } \\
\text { abnormalities in childhood }\end{array}$ & $\begin{array}{l}\text { The average amount of drug in breast milk } \\
\text { is higher with fluoxetine than with most other } \\
\text { SSRIs. Agents with lower excretion into breast } \\
\text { milk may be preferred, especially while } \\
\text { nursing a newborn or preterm infant }{ }^{87}\end{array}$ \\
\hline Methylphenidate & $\begin{array}{l}\text { A small increase in the risk of cardiac } \\
\text { malformations was noted in a large } \\
\text { international cohort study. }{ }^{88} \text { Use in pregnancy } \\
\text { may be associated with a small increased } \\
\text { relative risk of preeclampsia and preterm } \\
\text { birth }^{89}\end{array}$ & $\begin{array}{l}\text { Minimal transfer into breast milk. Limited } \\
\text { reports of no adverse effects on the nursling }\end{array}$ \\
\hline Modafinil & $\begin{array}{l}\text { See details regarding armodafinil and major } \\
\text { congenital malformations. Limited animal data } \\
\text { suggest alteration in immune and behavioral } \\
\text { effects that enhance vulnerability to } \\
\text { development of behavioral sensitization in } \\
\text { adulthood in prenatally exposed mice }\end{array}$ & $\begin{array}{l}\text { Human data available on transfer to breast milk } \\
\text { are limited. }{ }^{92} \text { The drug's small molecular } \\
\text { weight makes it likely to be transferred into } \\
\text { breast milk. By stimulating dopamine, the } \\
\text { drug may inhibit breast milk production }\end{array}$ \\
\hline Protriptyline & $\begin{array}{l}\text { Not anticipated to increase the risk of congenital } \\
\text { malformations. Withdrawal symptoms in the } \\
\text { newborns with exposure to tricyclic } \\
\text { antidepressants have been reported }\end{array}$ & $\begin{array}{l}\text { There are no available data on the transfer of } \\
\text { this drug into breast milk }\end{array}$ \\
\hline Selegiline & $\begin{array}{l}\text { Limited animal and human data. } \\
\text { Vasoconstrictive effect is concerning in } \\
\text { pregnancy }\end{array}$ & No safety data available \\
\hline Sodium oxybate & $\begin{array}{l}\text { Report of } 150 \text { cesarean deliveries performed } \\
\text { with sodium hydroxybutyrate has identified } \\
\text { maternal seizure, arterial hypertension, and } \\
\text { excessive blood loss as possibly being } \\
\text { associated with the use of the drug. Poor fetal } \\
\text { condition reported in } 12 \% \text { of subjects. }{ }^{94} \text { There } \\
\text { are no available studies to support safe use of } \\
\text { this drug to date }\end{array}$ & $\begin{array}{l}\text { Sodium oxybate is transmitted to breast milk. } \\
\text { GHB concentrations in milk remain high for } \\
\text { several hours following maternal } \\
\text { administration of the medication. To avoid } \\
\text { excess GHB exposure, breastfeeding mothers } \\
\text { who take sodium oxybate should consider } \\
\text { expressing and discarding their milk } 4-6 \mathrm{~h} \\
\text { after dosing }\end{array}$ \\
\hline Venlafaxine & $\begin{array}{l}\text { First-trimester in utero exposure to venlafaxine } \\
\text { is not associated with an increased risk of } \\
\text { major congenital malformations. }{ }^{96} \text { Transient } \\
\text { neonatal complications have been reported }\end{array}$ & $\begin{array}{l}\text { Transfer in milk found to be variable. Newborn } \\
\text { infants exposed in utero may experience poor } \\
\text { neonatal adaptation syndrome as seen with } \\
\text { other antidepressants such as SSRIs or SNRIs. } \\
\text { Use of venlafaxine during breastfeeding may } \\
\text { help to mitigate the symptoms of withdrawal } \\
\text { in infant }{ }^{97}\end{array}$ \\
\hline
\end{tabular}

GHB = gamma-hydroxybutyrate; SNRIs = serotonin-norepinephrine reuptake inhibitors. See Table 2 legend for expansion of other abbreviation. 
are often better tolerated. Cetirizine and loratadine have been the best studied drugs in pregnancy, and their use is justifiable. ${ }^{102}$

Key Points:

- Many nasal corticosteroids are believed to be safe for use in pregnancy.

- Use of systemic drugs such as cetirizine and loratadine is justified when topical medications are not effective.

Asthma: In the nonpregnant population, studies have reported a reciprocal interaction between asthma and OSA. ${ }^{103}$ Asthma has been associated with an increased risk of new-onset OSA ${ }^{104}$ and OSA linked to poor asthma control. ${ }^{105}$ Although poor asthma control may lead to sleep disruption, it is also important to recognize that nocturnal symptoms may be due to OSA and will not respond to escalating asthma interventions. Studies of this link between upper and lower airway disease have not included pregnant women; however, it is well established that poorly controlled asthma has been linked to adverse pregnancy outcomes. ${ }^{106}$ Therefore, recognition and diagnosis of OSA and treatment of asthma are critically important in pregnancy.

Although nonpharmacologic treatments, including patient education, smoking cessation, and control of environmental triggers, remain a cornerstone of therapy, medications should be used when indicated in pregnant women. Large, well-designed studies have shown the safety of inhaled corticosteroids and long- and shortacting beta-agonists. Budesonide is the inhaled corticosteroid with the best safety evidence; however, other inhaled corticosteroids are also safe and should be continued if a pregnant woman's condition is well controlled with these drugs. Although some clinicians are reluctant to add an additional drug in pregnancy, two studies have shown that the combination of inhaled corticosteroid/long-acting beta-agonist is as safe as higher dose inhaled corticosteroids. ${ }^{107,108}$ Registry data showed limb reduction defects with montelukast, leading to a change in the drug labeling by the FDA. ${ }^{109}$ Zileuton is best avoided in pregnancy due to inadequate data. ${ }^{110}$

Safety data for biologics are limited to registry data, with no human studies available. These monoclonal antibodies are expected to cross the placenta in the second half of pregnancy. Registry data of omalizumab in pregnancy $(n=169)$, including first-trimester use, indicate no increase in major congenital malformations, prematurity, or small-for-gestational-age births. ${ }^{111}$
Ongoing registries exist for anti-IL-5 antibody drugs. Systemic steroids should be used for the treatment of asthma exacerbations in pregnancy for the same indications as a nonpregnant woman, and the benefit, in this situation, outweighs the potential risk. Although some literature presents concerns about a small increased risk of congenital malformations (primarily cleft palate), preeclampsia, gestational diabetes, low birth weight, and prematurity, it is possible that these adverse outcomes are a consequence of severe uncontrolled asthma rather than the medication. ${ }^{112-114}$

Key Points:

- Asthma control in pregnancy is paramount and not just for sleep purposes.

- Use of most medications is justified, although some agents have a better safety profile than others.

\section{Pharmacologic Interventions in OSA}

In addition to established OSA therapy, which mainly relies on mechanical interventions that bypass or treat anatomical pathologies, pharmacotherapy is an attractive option in this condition, especially given the suboptimal adherence to positive airway therapy and the applicability of alternative therapies only in specific populations. OSA phenotypes that may be potential therapeutic targets include poor muscle responsiveness, an oversensitive ventilatory control system, and a low arousal threshold. However, a recent meta-analysis of the efficacy of pharmacotherapy for OSA in adults concluded that there is currently insufficient evidence to recommend pharmacotherapy for OSA. ${ }^{115}$ Nonetheless, a recently completed trial investigating the impact of atomoxetine, a norepinephrine reuptake inhibitor, and oxybutynin, an antimuscarinic drug, on OSA showed dramatic improvements in the apnea-hypopnea index. ${ }^{116}$ The relevance of the currently investigated drugs in the pregnant population is unclear because upper airway function, ventilatory control, and arousal physiology may all be different in this population due to the effect of significantly elevated levels of sex hormones ${ }^{4}$ and other pregnancy-specific factors. Hence, there is a need to better understand pregnancy-specific physiology of upper airway and ventilatory control prior to attempting the use of pharmacotherapy in this population.

\section{Conclusions}

Sleep disturbances and disorders are common in pregnancy. Decision-making regarding 
pharmacotherapy should take into consideration the efficacy of nonpharmacologic interventions, the impact of the condition on the mother or the fetus, and the availability of safer alternatives. A good understanding of the available safety data on drugs in pregnancy can inform maternal counseling and reduce unnecessary anxiety regarding medication use in pregnancy. Future research should ensure the inclusion of pregnant women in clinical trials to fill large gaps in our understanding of pharmacotherapy in this population. Many have argued that the exclusion, rather than the inclusion, of pregnant women from clinical trials is, in fact, unethical. ${ }^{117}$ The FDA has recently published a document that provides guidance on ethical and scientific considerations of pregnant women in clinical trials. ${ }^{118}$ Both the risk of teratogenicity as well as the pharmacokinetic properties of drugs need to be better understood in pregnant and lactating women. The fact that nearly $60 \%$ of all pregnant women in the United States use one medication during the course of pregnancy presents a valuable opportunity that would expand our knowledge regarding prescribing in pregnancy. Specific pathophysiological mechanisms underlying sleep disorders in pregnancy can further our understanding of these disorders in this dynamic state and set the stage for targeted interventions that may need to be pregnancyspecific.

\section{Acknowledgments}

Financial/nonfinancial disclosures: The authors have reported to CHEST the following: G. B. is funded by National Heart, Lung, and Blood Institute [R01HL130702] and the Eunice Kennedy Shriver National Institute of Child Health and Human Development [R01HD078515]. None declared (M. A. M., N. M., C. C.-B.).

\section{References}

1. National Sleep Foundation. Sleeping By the trimesters: 1st trimester. https://www.sleepfoundation.org/articles/sleepingtrimesters-1st-trimester. Accessed May 9, 2019.

2. Blyton DM, Sullivan CE, Edwards N. Lactation is associated with an increase in slow-wave sleep in women. J Sleep Res. 2002;11(4): 297-303.

3. Lee KA. Alterations in sleep during pregnancy and postpartum: a review of 30 years of research. Sleep Med Rev. 1998;2(4):231-242.

4. Bourjeily G, Chambers A, Salameh M, et al. Anthropometric measures and prediction of maternal sleep-disordered breathing. J Clin Sleep Med. 2019;15(6):849-856.

5. Pengo MF, Won CH, Bourjeily G. Sleep in women across the life span. Chest. 2018;154(1):196-206.

6. Oyiengo D, Louis M, Hott B, Bourjeily G. Sleep disorders in pregnancy. Clin Chest Med. 2014;35(3):571-587.

7. Gupta R, Dhyani M, Kendzerska T, et al. Restless legs syndrome and pregnancy: prevalence, possible pathophysiological mechanisms and treatment. Acta Neurol Scand. 2016;133(5):320329.

8. Okun ML, Buysse DJ, Hall MH. Identifying insomnia in early pregnancy: validation of the Insomnia Symptoms
Questionnaire (ISQ) in pregnant women. J Clin Sleep Med. 2015;11(6):645-654.

9. Okun ML, Kline CE, Roberts JM, Wettlaufer B, Glover K, Hall M. Prevalence of sleep deficiency in early gestation and its associations with stress and depressive symptoms. J Womens Health (Larchmt). 2013;22(12):1028-1037.

10. Dorheim SK, Bjorvatn B, Eberhard-Gran M. Insomnia and depressive symptoms in late pregnancy: a population-based study. Behav Sleep Med. 2012;10(3):152-166.

11. Picchietti DL, Hensley JG, Bainbridge JL, et al. Consensus clinical practice guidelines for the diagnosis and treatment of restless legs syndrome/Willis-Ekbom disease during pregnancy and lactation. Sleep Med Rev. 2015;22:64-77.

12. Scammell TE. Narcolepsy. N Engl J Med. 2015;373(27):26542662.

13. Maurovich-Horvat E, Kemlink D, Hogl B, et al. Narcolepsy and pregnancy: a retrospective European evaluation of 249 pregnancies. J Sleep Res. 2013;22(5):496-512.

14. Ping LS, Yat FS, Kwok WY. Status cataplecticus leading to the obstetric complication of prolonged labor. J Clin Sleep Med. 2007;3(1):56-57.

15. O’Brien LM, Bullough AS, Owusu JT, et al. Pregnancy-onset habitual snoring, gestational hypertension, and preeclampsia: prospective cohort study. Am J Obstet Gynecol. 2012;207(6). 487.e1e9.

16. Izci Balserak B. Sleep disordered breathing in pregnancy. Breathe (Sheff). 2015;11(4):268-277.

17. Facco FL, Parker CB, Reddy UM, et al. Association between sleep-disordered breathing and hypertensive disorders of pregnancy and gestational diabetes mellitus. Obstet Gynecol. 2017;129(1):31-41.

18. Reutrakul S, Zaidi N, Wroblewski K, et al. Interactions between pregnancy, obstructive sleep apnea, and gestational diabetes mellitus. J Clin Endocrinol Metab. 2013;98(10):4195-4202.

19. Pamidi S, Marc I, Simoneau G, et al. Maternal sleep-disordered breathing and the risk of delivering small for gestational age infants: a prospective cohort study. Thorax. 2016;71(8):719725.

20. Link BN, Eid C, Bublitz MH, et al. Pulse transit time in pregnancy: a new way to diagnose and classify sleep disordered breathing? Sleep. 2019;42(5).

21. Bublitz MH, Monteiro JF, Caraganis A, et al. Obstructive sleep apnea in gestational diabetes: a pilot study of the role of the hypothalamic-pituitary-adrenal axis. J Clin Sleep Med. 2018;14(1): 87-93.

22. Mitchell AA, Gilboa SM, Werler MM, Kelley KE, Louik C, Hernandez-Diaz S. Medication use during pregnancy, with particular focus on prescription drugs: 1976-2008. Am J Obstet Gynecol. 2011;205(1):51.e51-58.

23. US Food and Drug Administration, HHS. Content and Format of Labeling for Human Prescription Drug and Biological Products; Requirements for Pregnancy and Lactation Labeling. https:// federalregister.gov/a/2014-28241. Accessed April 22, 2019.

24. Reproductive Toxicology Center. www.reprotox.org. Accessed April 19, 2019.

25. MotherToBaby. https://mothertobaby.org/. Accessed May 9, 2019.

26. Bartick MC, Schwarz EB, Green BD, et al. Suboptimal breastfeeding in the United States: maternal and pediatric health outcomes and costs. Matern Child Nutr. 2017;13(1).

27. Anderson PO, Sauberan JB. Modeling drug passage into human milk. Clin Pharmacol Ther. 2016;100(1):42-52.

28. National Library of Medicine, National Institutes of Health. LactMed. A TOXNET database. https://toxnet.nlm.nih.gov/ newtoxnet/lactmed.htm. Accessed May 9, 2019.

29. Khan MS, Aouad R. The effects of insomnia and sleep loss on cardiovascular disease. Sleep Med Clin. 2017;12(2):167-177. 
30. Hayase M, Shimada M, Seki H. Sleep quality and stress in women with pregnancy-induced hypertension and gestational diabetes mellitus. Women Birth. 2014;27(3):190-195.

31. Warland J, Dorrian J, Morrison JL, O’Brien LM. Maternal sleep during pregnancy and poor fetal outcomes: a scoping review of the literature with meta-analysis. Sleep Med Rev. 2018;41:197-219.

32. Palagini L, Gemignani A, Banti S, Manconi M, Mauri M, Riemann D. Chronic sleep loss during pregnancy as a determinan of stress: impact on pregnancy outcome. Sleep Med. 2014;15(8): 853-859.

33. Osnes RS, Roaldset JO, Follestad T, Eberhard-Gran M. Insomnia late in pregnancy is associated with perinatal anxiety: a longitudinal cohort study. J Affect Disord. 2019;248:155-165.

34. Park EM, Meltzer-Brody S, Stickgold R. Poor sleep maintenance and subjective sleep quality are associated with postpartum maternal depression symptom severity. Arch Womens Ment Health 2013;16(6):539-547.

35. Reichner CA. Insomnia and sleep deficiency in pregnancy. Obstet Med. 2015;8(4):168-171.

36. Volkow ND, Han B, Compton WM, McCance-Katz EF. Selfreported medical and nonmedical cannabis use among pregnant women in the United States. JAMA. 2019;322(2):167-169.

37. Silverstein M, Howell EA, Zuckerman B. Cannabis use in pregnancy: a tale of 2 concerns. JAMA. 2019;322(2):121-122.

38. Corsi DJ, Walsh L, Weiss D, et al. Association between selfreported prenatal cannabis use and maternal, perinatal, and neonatal outcomes. JAMA. 2019;322(2):145-152.

39. Sedov ID, Goodman SH, Tomfohr-Madsen LM. Insomnia treatment preferences during pregnancy. J Obstet Gynecol Neonatal Nurs. 2017;46(3):e95-e104.

40. Sedov I, Madsen JW, Goodman SH, Tomfohr-Madsen LM. Couples' treatment preferences for insomnia experienced during pregnancy. Fam Syst Health. 2019;37(1):46-55.

41. Manber R, Bei B, Simpson N, et al. Cognitive behavioral therapy for prenatal insomnia: a randomized controlled trial. Obstet Gynecol. 2019;133(5):911-919.

42. Tomfohr-Madsen LM, Clayborne ZM, Rouleau CR, Campbell TS. Sleeping for two: an open-pilot study of cognitive behavioral therapy for insomnia in pregnancy. Behav Sleep Med. 2017;15(5): 377-393.

43. Greenberg G, Inman WH, Weatherall JA, Adelstein AM, Haskey JC. Maternal drug histories and congenital abnormalities. Br Med J. 1977;2(6091):853-856.

44. Winship KA, Cahal DA, Weber JC, Griffin JP. Maternal drug histories and central nervous system anomalies. Arch Dis Child. 1984;59(11):1052-1060.

45. American Academy of Pediatrics Committee on Drugs. Transfer of drugs and other chemicals into human milk. Pediatrics. 2001;108(3):776-789.

46. World Health Organization, UNICEF. Breastfeeding and Maternal Medication. Recommendations for Drugs in the Eleventh WHO Model List of Essential Drugs. 2002; https://www.who.int/ maternal_child_adolescent/documents/55732/en/. Accessed October 28, 2019.

47. Anderka M, Mitchell AA, Louik C, et al. Medications used to treat nausea and vomiting of pregnancy and the risk of selected birth defects. Birth Defects Res A Clin Mol Teratol. 2012;94(1): 22-30.

48. Gilboa SM, Strickland MJ, Olshan AF, Werler MM, Correa A National Birth Defects Prevention Study. Use of antihistamine medications during early pregnancy and isolated major malformations. Birth Defects Res A Clin Mol Teratol. 2009;85(2): 137-150.

49. Saxen I. Letter: cleft palate and maternal diphenhydramine intake. Lancet. 1974;1(7854):407-408.

50. Bennett PN, World Health Organization Working Group. Drugs and Human Lactation: A Guide to the Content and Consequences of Drugs, Micronutrients, radiopharmaceuticals, and Environmental and Occupational Chemicals in Human Milk. New York, NY: Elsevier; 1988.

51. Richardson G, Wang-Weigand S. Effects of long-term exposure to ramelteon, a melatonin receptor agonist, on endocrine function in adults with chronic insomnia. Hum Psychopharmacol. 2009;24(2): 103-111.

52. US Food and Drug Administration. Ramelteon. https://www. accessdata.fda.gov/drugsatfda docs/label/2005/021782lbl.pdf. Accessed May 10, 2019.

53. Kargas GA, Kargas SA, Bruyere HJ Jr, Gilbert EF, Opitz JM. Perinatal mortality due to interaction of diphenhydramine and temazepam. N Engl J Med. 1985;313(22):1417-1418.

54. Ban L, West J, Gibson JE, et al. First trimester exposure to anxiolytic and hypnotic drugs and the risks of major congenital anomalies: a United Kingdom population-based cohort study. PLoS One. 2014;9(6):e100996.

55. Einarson A, Bonari L, Voyer-Lavigne S, et al. A multicentre prospective controlled study to determine the safety of trazodone and nefazodone use during pregnancy. Can J Psychiatry. 2003;48(2):106-110

56. Einarson A, Choi J, Einarson TR, Koren G. Incidence of major malformations in infants following antidepressant exposure in pregnancy: results of a large prospective cohort study. Can J Psychiatry. 2009;54(4):242-246.

57. McElhatton PR, Garbis HM, Eléfant E, et al. The outcome of pregnancy in 689 women exposed to therapeutic doses of antidepressants. A collaborative study of the European Network of Teratology Information Services (ENTIS). Reproductive Toxicology. 1996;10(4):285-294.

58. Newport DJ, Ritchie JC, Knight BT, Glover BA, Zach EB, Stowe ZN. Venlafaxine in human breast milk and nursing infant plasma: determination of exposure. J Clin Psychiatry. 2009;70(9): 1304-1310.

59. Wikner BN, Kallen B. Are hypnotic benzodiazepine receptor agonists teratogenic in humans? J Clin Psychopharmacol. 2011;31(3):356-359.

60. Darwish M, Martin PT, Cevallos WH, Tse S, Wheeler S, Troy SM. Rapid disappearance of zaleplon from breast milk after oral administration to lactating women. J Clin Pharmacol. 1999;39(7): 670-674.

61. Umemura T, Yamaguchi K, Watanabe M, Esaki K, Kawamoto H, Yanagita T. Influence of zopiclone on male reproductivity in rats. Res Commun Chem Pathol Pharmacol. 1987;56(2):165-184.

62. Kallen B, Borg N, Reis M. The use of central nervous system active drugs during pregnancy. Pharmaceuticals (Basel). 2013;6(10):12211286 .

63. Diav-Citrin O, Okotore B, Lucarelli K, Koren G. Pregnancy outcome following first-trimester exposure to zopiclone: a prospective controlled cohort study. Am J Perinatol. 1999;16(4) 157-160.

64. Stephens S, Wilson G, Gilfillan C, McElhatton PR, Thomas SH. Preliminary data on therapeutic exposure to zopiclone during pregnancy. Reprod Toxicol. 2008;26(1):73-74.

65. Mathieu OM, Thompson M, Leplaya M, Mazurierb E, HillaireBuysa D. Case report: in utero exposure and safe breastfeeding in two premature twins of a chronically treated mother with high doses of zopiclone. Fundam Clin Pharmacol. 2010;24(suppl 1):424. Abstract.

66. Wang LH, Lin HC, Lin CC, Chen YH, Lin HC. Increased risk of adverse pregnancy outcomes in women receiving zolpidem during pregnancy. Clin Pharmacol Ther. 2010;88(3):369-374.

67. Pons G, Francoual C, Guillet P, et al. Zolpidem excretion in breast milk. Eur J Clin Pharmacol. 1989;37(3):245-248.

68. Davis FC. Melatonin: role in development. J Biol Rhythms. 1997;12(6):498-508.

69. Colmenero MD, Diaz B, Miguel JL, Gonzalez ML, Esquifino A, Marin B. Melatonin administration during pregnancy retards sexual maturation of female offspring in the rat. J Pineal Res. 1991;11(1):23-27. 
70. Dubovicky M, Ujhazy E, Kovacovsky P, Navarova J, Jurani M, Soltes L. Effect of melatonin on neurobehavioral dysfunctions induced by intrauterine hypoxia in rats. Cent Eur J Public Health. 2004;12(suppl):S23-S25.

71. Dominguez Rubio AP, Correa F, Aisemberg J, et al. Maternal administration of melatonin exerts short- and long-term neuroprotective effects on the offspring from lipopolysaccharidetreated mice. J Pineal Res. 2017;63(4).

72. Palmer KR, Mockler JC, Davies-Tuck ML, et al. Protect-me: a parallel-group, triple blinded, placebo-controlled randomised clinical trial protocol assessing antenatal maternal melatonin supplementation for fetal neuroprotection in early-onset fetal growth restriction. BMJ Open. 2019;9(6):e028243.

73. Khazaie H, Ghadami MR, Knight DC, Emamian F, Tahmasian M. Insomnia treatment in the third trimester of pregnancy reduces postpartum depression symptoms: a randomized clinical trial. Psychiatry Res. 2013;210(3):901-905.

74. Dunietz GL, Lisabeth LD, Shedden K, et al. Restless legs syndrome and sleep-wake disturbances in pregnancy. J Clin Sleep Med. 2017;13(7):863-870.

75. Ma S, Shang X, Guo Y, Liu G, Yang J, Xue R. Restless legs syndrome and hypertension in Chinese pregnant women. Neurol Sci. 2015;36(6):877-881.

76. Ramirez JO, Cabrera SA, Hidalgo H, et al. Is preeclampsia associated with restless legs syndrome? Sleep Med. 2013;14(9):894896.

77. Innes KE, Kandati S, Flack KL, Agarwal P, Selfe TK. The association of restless legs syndrome to history of gestational diabetes in an Appalachian primary care population. J Clin Sleep Med. 2015;11(10):1121-1130.

78. Tan M, Bourjeily G. Shaking up perspectives of restless legs syndrome in pregnancy. J Clin Sleep Med. 2017;13(7):857-858.

79. Achebe MM, Gafter-Gvili A. How I treat anemia in pregnancy: iron, cobalamin, and folate. Blood. 2017;129(8):940-949.

80. Qassim A, Mol BW, Grivell RM, Grzeskowiak LE. Safety and efficacy of intravenous iron polymaltose, iron sucrose and ferric carboxymaltose in pregnancy: a systematic review. Aust $N Z J$ Obstet Gynaecol. 2018;58(1):22-39.

81. Thorpy M, Zhao CG, Dauvilliers Y. Management of narcolepsy during pregnancy. Sleep Med. 2013;14(4):367-376.

82. Sachs HC. The transfer of drugs and therapeutics into human breast milk: an update on selected topics. Pediatrics. 2013;132(3): e796-e809.

83. Health Canada, Government of Canada. ALERTEC (modafinil) and the Risk of Congenital Anomalies. http://www. healthycanadians.gc.ca/recall-alert-rappel-avis/hc-sc/2019/70201aeng.php. 2019. Accessed July 1, 2019.

84. Aurora S, Aurora N, Datta P, Rewers-Felkins K, Baker T, Hale TW Evaluating transfer of modafinil into human milk during lactation: a case report. J Clin Sleep Med. 2018;14(12):2087-2089.

85. Kallen B, Otterblad Olausson P. Antidepressant drugs during pregnancy and infant congenital heart defect. Reprod Toxicol. 2006;21(3):221-222.

86. ter Horst PG, van der Linde S, Smit JP, et al. Clomipramine concentration and withdrawal symptoms in 10 neonates. $\mathrm{Br}$ J Clin Pharmacol. 2012;73(2):295-302.

87. Clinical Pharmacology Database. Fluoxetine. https://www.elsevier. com/solutions/clinical-pharmacology. Elsevier, 2019. Accessed May $10,2019$.

88. Huybrechts KF, Broms G, Christensen LB, et al. Association between methylphenidate and amphetamine use in pregnancy and risk of congenital malformations: a cohort study from the International Pregnancy Safety Study Consortium. JAMA Psychiatry. 2018;75(2):167-175.

89. Cohen JM, Hernandez-Diaz S, Bateman BT, et al. Placental complications associated with psychostimulant use in pregnancy. Obstet Gynecol. 2017;130(6):1192-1201.

90. Ruda-Kucerova J, Amchova P, Machalova A, Pistovcakova J, Sulcova A. Prenatal exposure to modafinil alters locomotor behaviour and leucocyte phagocytosis in mice. Psychiatr Danub. 2018;30(3):356-366.

91. Ruda-Kucerova J, Pistovcakova J, Amchova P, Sulcova A, Machalova A. Prenatal exposure to modafinil alters behavioural response to methamphetamine in adult male mice. Int J Dev Neurosci. 2018;67:37-45.

92. LactMed database. https://toxnet.nlm.nih.gov/newtoxnet/lactmed. htm. Accessed April 19, 2019.

93. Webster PA. Withdrawal symptoms in neonates associated with maternal antidepressant therapy. Lancet. 1973;2(7824):318-319.

94. Laget-Corsin L, Baroche J. Anesthesia with sodium gammahydroxybutyrate in cesarean section [in French]. Anesth Analg (Paris). 1972;29(1):43-49.

95. Barker EC, Puchowicz M, Letterio J, Higgins K, Sharkey KM. GHB levels in breast milk of women with narcolepsy with cataplexy treated with sodium oxybate. Sleep Med. 2017;36:172-177.

96. Lassen D, Ennis ZN, Damkier P. First-trimester pregnancy exposure to venlafaxine or duloxetine and risk of major congenital malformations: a systematic review. Basic Clin Pharmacol Toxicol. 2016;118(1):32-36.

97. Koren G, Moretti M, Kapur B. Can venlafaxine in breast milk attenuate the norepinephrine and serotonin reuptake neonatal withdrawal syndrome. J Obstet Gynaecol Can. 2006;28(4):299-301.

98. Calais CJ, Robertson BD, Beakes DE. Association of allergy/ immunology and obstructive sleep apnea. Allergy Asthma Proc. 2016;37(6):443-449.

99. Alhussien AH, Alhedaithy RA, Alsaleh SA. Safety of intranasal corticosteroid sprays during pregnancy: an updated review. Eur Arch Otorhinolaryngol. 2018;275(2):325-333.

100. Berard A, Sheehy O, Kurzinger ML, Juhaeri J. Intranasal triamcinolone use during pregnancy and the risk of adverse pregnancy outcomes. J Allergy Clin Immunol. 2016;138(1). 97-104. e107.

101. Wilson J. Use of sodium cromoglycate during pregnancy. J Pharm Med. 1982;8:45-51.

102. Kallen B. Use of antihistamine drugs in early pregnancy and delivery outcome. J Matern Fetal Neonatal Med. 2002;11(3):146152.

103. Owens RL, Macrea MM, Teodorescu M. The overlaps of asthma or COPD with OSA: a focused review. Respirology. 2017;22(6):10731083.

104. Teodorescu M, Barnet JH, Hagen EW, Palta M, Young TB, Peppard PE. Association between asthma and risk of developing obstructive sleep apnea. JAMA. 2015;313(2):156-164.

105. Teodorescu M, Broytman O, Curran-Everett D, et al. Obstructive sleep apnea risk, asthma burden, and lower airway inflammation in adults in the Severe Asthma Research Program (SARP) II. J Allergy Clin Immunol Pract. 2015;3(4). 566-575.e561.

106. Bonham CA, Patterson KC, Strek ME. Asthma outcomes and management during pregnancy. Chest. 2018;153(2):515-527.

107. Eltonsy S, Forget A, Beauchesne MF, Blais L. Risk of congenital malformations for asthmatic pregnant women using a long-acting beta(2)-agonist and inhaled corticosteroid combination versus higher-dose inhaled corticosteroid monotherapy. J Allergy Clin Immunol. 2015;135(1):123-130.

108. Cossette B, Beauchesne MF, Forget A, et al. Relative perinatal safety of salmeterol vs formoterol and fluticasone vs budesonide use during pregnancy. Ann Allergy Asthma Immunol. 2014;112(5):459464.

109. Cavero-Carbonell C, Vinkel-Hansen A, Rabanque-Hernandez MJ, Martos C, Garne E. Fetal exposure to montelukast and congenital anomalies: a population based study in Denmark. Birth Defects Res. 2017;109(6):452-459.

110. Zileuton. Agent summary. https://reprotox.org/member/agents/23 969. Accessed April 22, 2019.

111. Namazy J, Cabana MD, Scheuerle AE, et al. The Xolair Pregnancy Registry (EXPECT): the safety of omalizumab use during pregnancy. J Allergy Clin Immunol. 2015;135(2):407-412. 
112. Schatz M, Dombrowski MP, Wise R, et al. The relationship of asthma medication use to perinatal outcomes. J Allergy Clin Immunol. 2004;113(6):1040-1045.

113. Bracken MB, Triche EW, Belanger K, Saftlas A, Beckett WS, Leaderer BP. Asthma symptoms, severity, and drug therapy: a prospective study of effects on 2205 pregnancies. Obstet Gynecol. 2003;102(4):739-752.

114. Namazy JA, Murphy VE, Powell H, Gibson PG, Chambers C, Schatz M. Effects of asthma severity, exacerbations and oral corticosteroids on perinatal outcomes. Eur Respir J. 2013;41(5):1082-1090.

115. Gaisl T, Haile SR, Thiel S, Osswald M, Kohler M. Efficacy of pharmacotherapy for OSA in adults: a systematic review and network meta-analysis. Sleep Med Rev. 2019;46:74-86.
116. Taranto-Montemurro L, Messineo L, Sands SA, et al. The combination of atomoxetine and oxybutynin greatly reduces obstructive sleep apnea severity. A randomized, placebo-controlled, double-blind crossover trial. Am J Respir Crit Care Med. 2019;199(10):1267-1276.

117. Rubin R. Addressing barriers to inclusion of pregnant women in clinical trials. JAMA. 2018;320(8):742-744.

118. US Food and Drug Administration, HHS. Pregnant Women: Scientific and Ethical Considerations for Inclusion in Clinical Trials; Draft Guidance; Availability. https://www.federalregister. gov/documents/2018/04/09/2018-07151/pregnant-womenscientific-and-ethical-considerations-for-inclusion-in-clinicaltrials-draft-guidance. Accessed July 1, 2019. 